\title{
Health behaviours and body image of girls in the second phase of adolescence
}

\section{BACKGROUND}

The concept of body image was introduced by Paul Schilder, who recognised that this is a picture of our own body, which we create in our mind and which is the way in which the body is revealed to us. He proposed a definition centred around the cognitive aspect and assumed the relative stability of this structure. However, he highlighted the fact that the body image may be shaped by various experiences, and thus an individual can modify his own body image during life.

\section{PARTICIPANTS AND PROCEDURE}

The study group consisted of 112 high school students aged 17 and 18 years. The study was conducted from March to June 2014 in Poland. Techniques: The Body Esteem Scale (BES) by S. Franzoi and S. Shields was used for the purpose of the research. The scale is used to study body image. The second tool used in the research was the Health Behaviour Inventory $(\mathrm{HBI})$ by $\mathrm{Z}$. Juczyński. Although the standards are set for adults, the same tool is frequently used in research among youth.

\section{RESULTS}

It was found that only the overall health behaviour indicator correlates with body evaluation. The higher the overall health behaviour indicator was, the higher was body evaluation among the girls involved in the study. However, no significant correlation was found between body mass index (BMI) and overall body evaluation.

\section{CONCLUSIONS}

The research demonstrated that the body image of adolescent girls significantly correlates with their health care to a large extent and with the desire to be slim to a lesser extent. This is a very positive result considering the idea of a healthy lifestyle.

KEY WORDS

body image; adolescence; girls; health behaviour 


\section{BACKGROUND}

Nowadays, an athletic and often excessively slim figure is promoted by society. Paradoxically enough, one of the major health problems in the world is obesity (Davidson \& Knafl, 2006). This issue does not only affect highly developed, wealthy countries, in which a growing number of obese and overweight individuals has been reported for many years, but also the developing countries. Furthermore, people in developing countries gain weight due to consuming imported, unhealthy and highly processed but inexpensive food (Seidell, 1995). According to WHO data, in 2008 more than $50 \%$ of adults in Europe were overweight, whereas approximately $20 \%$ suffered from obesity (James, Rigby, \& Leach, 2004). It is therefore very important to undertake research on behaviour allowing the risk of abnormal body weight and related diseases to be minimized. On the other hand, many people, in particular young ones, suffer from diseases resulting from being underweight. Their desire to achieve an "ideal" body weight (promoted by some mass media among others) frequently results in emaciation and negative health consequences. Psychological and social costs, including the material ones related to treatment and therapy, for both obesity and emaciation are large indeed. However, the body image changes during the life (Tiggemann, 2004; Lipowska \& Lipowski, 2006, 2013). This justifies the need for research on body image among adolescents, their health behaviour and the correlations between them as well as on their psychosocial determinants. The findings of these studies may provide a basis for developing eating disorder prevention programs and healthy lifestyle development and promotion programs.

Shaping healthy eating habits and an appropriate level of physical activity appears to be especially effective during childhood and adolescence (Must \& Strauss, 1999). Problems caused by lifestyle choices, including diet and physical activity, vary depending on different subjective factors such as sex (Kelder, Perry, Klepp, \& Lytle, 1994). Specialist literature reports and results of pilot studies indicate a high level of risk connected with adolescent girls taking drastic measures focused on weight loss (Thompson, Coovert, Richards, Johnson, \& Cattarin, 1995). For this reason, in the present study we investigated the body image of teenage girls, their health behaviour and the relationship between them.

\section{HEALTH BEHAVIOURS}

Health behaviours can be defined in different ways depending on the scientific discipline. It is generally accepted that this is the kind of behaviour that affects the length and quality of life (O'Dea \& Abraham,
2000). For the formation of correct behaviour patterns, the period of childhood and adolescence is particularly important. The literature provides numerous lists of health-oriented behaviours, which usually include eating habits, physical activity, coping with stress and avoiding stimulants and addictive substances (drugs, alcohol, tobacco and others) (Cinelli \& O’Dea, 2009). According to some authors, health-oriented attitudes determine $50 \%$ of the variance of results (Lalonde, 1974 as cited in Słonka \& Rektor, 2005).

From a medical point of view, developing the correct health behaviour patterns is essential for physical condition, the proper course of physiological processes and metabolism as well as the absence of disease symptoms. The attitudes toward health and the health behaviour habits are related to the perception of one's own body. The body image is a part of the concept of "self" and reflects the knowledge about oneself, including appearance, health, etc. This perception is also connected with self-esteem. This indicates the role of social context of the body image. So far there has been little research into correlations between health attitudes and psychological variables, including the sense of corporeity and body image.

\section{BODY IMAGE}

In recent years the importance of the body or the sense of corporeity for human functioning has been appreciated by a number of researchers (Friedman \& Brownell, 1995). Some studies have revealed that a positive esteem of the body has a beneficial effect on human psychosocial functioning. However, the literature presents a lot of concepts associated with physicality and describes psychological aspects of body image in different terms such as body diagram, body concept or the sense of corporeity. Many researchers have focused on identifying body image and body image disorders as well as health-oriented behaviour correlations - ignoring or simply marginalising psychological issues. Body image is a multidimensional construct, and researchers do not agree about the way of understanding this concept. The concept of body image was introduced by Paul Schilder, who recognised that this is a picture of our own body, which we create in our mind, and which is the way in which the body is revealed to us (Epstein, Klein, \& Wisniewski, 1994). He proposed a definition centred around the cognitive aspect and assumed the relative stability of this structure. However, he highlighted the fact that body image may be shaped by various experiences, and thus an individual can modify his own body image during life.

A distorted image of one's body can provide a source of suffering and mental discomfort experienced by many people (Eisenberg, Neumark-Sztainer, \& Story, 2003; Vila et al., 2004). The purpose of 
our surveys was to analyse the factors which may significantly affect the individual's own body image. According to the literature, many teenagers have an exceptionally negative evaluation of their own body image (Cash, Morrow, Hrabosky, \& Perry, 2004; Schwartz \& Brownell, 2004). That is why it seems to be so significant to undertake studies on the factors which may be related to satisfaction with one's body during adolescence.

\section{PARTICIPANTS AND PROCEDURE}

\section{METHOD}

The objective of this study was to analyse health-oriented behaviour of girls in the age range of 17 to 18 years and to determine their body image. We analysed the relationship between health-oriented behaviour and body evaluation and body weight in adolescent girls. Reports from medical and psychological journals indicate a higher incidence of health disorders and psychosocial functioning disorders associated with the perception of one's own body in girls than in boys. For this reason, the research involved a group of adolescent girls.

\section{SAMPLE AND TECHNIQUES}

The study group consisted of 112 high school students aged 17 and 18 years. The study was conducted from March to June 2014 in Poland.

The Body Esteem Scale (BES) by S. Franzoi and S. Shields (1984), adapted to Polish by Lipowska and Lipowski (2013), was used for the research. The scale is used to study body image. The BES consisted of 35 items which in turn were composed of three subscales, different for women and men. The study of women included the following subscales: (1) sexual attractiveness, (2) weight control, and (3) physical condition, while the subscales used in the study of men were as follows: (1) physical attractiveness,
(2) body strength, and (3) physical condition. The reliability indicator (Cronbach's $\alpha$ ) of BES for women is high and ranges from .78 for the sexual attractiveness subscale to .87 for the weight control subscale. For male respondents, the indicator of reliability was .81 for the subscale of physical attractiveness and .86 for the physical condition subscale (Franzoi \& Shields, 1984). Thus, the indicators are satisfactory.

The second tool used in the research was the Health Behaviour Inventory (HBI) by Z. Juczyński (2001). Although the standards are set for adults, the same tool is frequently used for the purpose of research among youth. For this reason, the present study also used the HBI. The tool includes 24 statements which make up 4 subscales: eating habits, preventive behaviour, positive mental attitude and health practice. Reliability and aptness of the questionnaire are satisfactory (Juczyński, 2001). The general indicator of health behaviour intensity measured using the HBI scale ranges from 24 to 120 points. The higher the score, the greater is the intensity of reported health behaviour.

\section{RESULTS}

The analysis determined an overall indicator of health behaviour intensity and the degree of intensity of the four categories of the said behaviour in the sample group within the four following aspects of health behaviour: (a) proper nutrition $(\mathrm{PN})$ considering mainly the kind of the food eaten, (b) prophylactic behaviour (PB) regarding the compliance with health recommendations and obtaining information on health and disease, (c) health practice (HP), namely, daily habits of sleeping, relaxing and physical activity, and (d) a positive mental attitude (PMA) concerning avoiding strong emotions, stress and situations causing depression. The measurement results are shown in Table 1.

For the purpose of results interpretation we used the Polish standards for adults developed by Juczyński (2001) as it was assumed that 17-18-year-old individuals are entering the adulthood stage (emerg-
Health behaviour and body image

Table 1

Means of each category of IZZ scale (subjects: girls)

\begin{tabular}{lcccccc}
\hline Variable & $\begin{array}{c}\text { Number } \\
\text { of girls }\end{array}$ & $M$ & $\min$ & $\max$ & $S D$ & Variance \\
\hline $\begin{array}{l}\text { General indicator of health } \\
\text { behaviour IZZ }\end{array}$ & 112 & 76.91 & 40.00 & 117.00 & 14.04 & 197.06 \\
Proper nutrition (PN) & 112 & 3.11 & 1.33 & 5.00 & 0.72 & 0.52 \\
Prophylactic behaviour (PB) & 112 & 3.10 & 1.00 & 4.67 & 0.86 & 0.73 \\
Positive mental attitude (PMA) & 112 & 3.33 & 1.00 & 5.00 & 0.80 & 0.64 \\
Health practice (HP) & 112 & 3.27 & 1.50 & 5.00 & 0.71 & 0.50 \\
\hline
\end{tabular}


Hanna Liberska, Klaudia Boniecka ing adulthood). The results obtained reveal that the youth involved in the study can be characterised by an average health behaviour intensity.

The second stage of the analysis provided information on the correlations between body mass in$\operatorname{dex}(\mathrm{BMI})$ and the other variables tested in the study (evaluation of body image and health behaviour). Spearman's rank correlation coefficient was used (Table 2).

It was found that only the overall health behaviour indicator correlates with body evaluation. The higher the overall health behaviour indicator, the higher was the body evaluation among the girls involved in the study. However, no significant correlation was found between BMI and overall body evaluation.

The further analyses focused on testing correlations between categories related to health behaviour and categories of body evaluations. The results are presented in Table 3.

A significant positive correlation was found between the overall health behaviour indicator and the general body evaluation (.48) as well as all the subscales within this scale (.42-.43). Statistically significant correlations were found between all the HBI subscales and the overall body evaluation. However,

Table 2

Correlations between indicator of body mass index (BMI), evaluation of body image and health-related behaviour (Spearman's r coefficient)

\begin{tabular}{lccc}
\hline Variable & BMI & $\begin{array}{c}\text { Overall health } \\
\text { behaviour (IZZ) }\end{array}$ & Body evaluation \\
\hline BMI & 1.00 & -0.15 & 0.04 \\
Overall health behaviour (IZZ) & -0.15 & 1.00 & $0.46^{*}$ \\
\hline
\end{tabular}

Note. ${ }^{*} p<.05$

Table 3

Value of correlations between subscale of image of own body and health-related behaviour (Spearman's r coefficient)

\begin{tabular}{|c|c|c|c|c|c|c|c|c|c|}
\hline \multicolumn{10}{|c|}{ Correlations between treatment variables in youth group $(N=112)$} \\
\hline Variable & $\begin{array}{c}\text { IZZ } \\
\text { general } \\
\text { indicator } \\
\text { of health } \\
\text { behaviour }\end{array}$ & $\begin{array}{c}\text { PN } \\
\text { proper } \\
\text { nutri- } \\
\text { tion }\end{array}$ & $\begin{array}{c}\text { PB } \\
\text { prophy- } \\
\text { lactic } \\
\text { behav- } \\
\text { iour }\end{array}$ & $\begin{array}{c}\text { PMA } \\
\text { pos- } \\
\text { itive } \\
\text { mental } \\
\text { atti- } \\
\text { tude }\end{array}$ & $\begin{array}{c}\text { HP } \\
\text { health } \\
\text { practice }\end{array}$ & $\begin{array}{c}\text { AS } \\
\text { sexual } \\
\text { attrac- } \\
\text { tive- } \\
\text { ness }\end{array}$ & $\begin{array}{c}\text { KW } \\
\text { weight } \\
\text { control }\end{array}$ & $\begin{array}{l}\text { KF } \\
\text { phys- } \\
\text { ical } \\
\text { condi- } \\
\text { tion }\end{array}$ & $\begin{array}{c}\text { General } \\
\text { body } \\
\text { evaluation }\end{array}$ \\
\hline $\begin{array}{l}\text { General indi- } \\
\text { cator of health } \\
\text { behaviour (IZZ) }\end{array}$ & 1.00 & $0.65^{*}$ & $0.84^{*}$ & $0.76^{*}$ & $0.76^{*}$ & $0.42^{*}$ & $0.43^{*}$ & $0.43^{*}$ & $0.48^{*}$ \\
\hline $\begin{array}{l}\text { Proper nutri- } \\
\text { tion }(\mathrm{PN})\end{array}$ & $0.65^{*}$ & 1.00 & $0.45^{*}$ & $0.21^{*}$ & $0.37^{*}$ & $0.21^{*}$ & 0.17 & 0.16 & $0.20^{*}$ \\
\hline $\begin{array}{l}\text { Prophylactic } \\
\text { behaviour (PB) }\end{array}$ & $0.84^{*}$ & $0.45^{*}$ & 1.00 & $0.57^{*}$ & $0.48^{*}$ & $0.34^{*}$ & $0.37^{*}$ & $0.33^{*}$ & $0.39^{*}$ \\
\hline $\begin{array}{l}\text { Positive mental } \\
\text { attitude (PMA) }\end{array}$ & $0.76^{*}$ & $0.21^{*}$ & $0.57^{*}$ & 1.00 & $0.48^{*}$ & $0.43^{*}$ & $0.42^{*}$ & $0.53^{*}$ & $0.51^{*}$ \\
\hline $\begin{array}{l}\text { Health practice } \\
\text { (HP) }\end{array}$ & $0.76^{*}$ & $0.37^{*}$ & $0.48^{*}$ & $0.48^{*}$ & 1.00 & $0.28^{*}$ & $0.33^{*}$ & $0.28^{*}$ & $0.34^{*}$ \\
\hline $\begin{array}{l}\text { AS sexual } \\
\text { attractiveness }\end{array}$ & $0.42^{*}$ & $0.21^{*}$ & $0.34^{*}$ & $0.43^{*}$ & $0.28^{*}$ & 1.00 & $0.71^{*}$ & $0.67^{*}$ & $0.91^{*}$ \\
\hline $\begin{array}{l}\mathrm{KW} \text { weight } \\
\text { control }\end{array}$ & $0.43^{*}$ & 0.17 & $0.37^{*}$ & $0.42^{*}$ & $0.33^{*}$ & $0.72^{*}$ & 1.00 & $0.62^{*}$ & $0.91^{*}$ \\
\hline $\begin{array}{l}\text { KF physical } \\
\text { condition }\end{array}$ & $0.43^{*}$ & 0.16 & $0.33^{*}$ & $0.53^{*}$ & $0.28^{*}$ & $0.67^{*}$ & $0.62^{*}$ & 1.00 & $0.83^{*}$ \\
\hline $\begin{array}{l}\text { General body } \\
\text { evaluation }\end{array}$ & $0.48^{*}$ & $0.20^{*}$ & $0.39^{*}$ & $0.51^{*}$ & $0.34^{*}$ & $0.91^{*}$ & $0.92^{*}$ & $0.83^{*}$ & 1.00 \\
\hline
\end{tabular}

Note. ${ }^{*} p<.05$ 
the strongest relationship was found in the case of a positive mental attitude (.51).

\section{DISCUSSION}

Nowadays, some young people perceive a slim figure as a benchmark of health and an ideal of beauty they aspire to. Promotion of an excessively thin body by the media frequently stimulates people, in particular young ones, to reduce their body weight without taking into account the advice of doctors and nutritionists regarding proper eating habits, avoiding stimulants or regular physical activity (Blair, Cheng, \& Holder, 2001; Paeratakul, Ferdinand, Champagne, Ryan, \& Bray, 2003; Vereecken, de Henauw, \& Maes, 2005). One of the consequences is the recently observed skinny fat phenomenon which involves an individual maintaining correct or very low body mass and a considerable amount of fat tissue at the same time. Such a chemical imbalance and distorted body structure is increasingly concerning from the medical point of view. Nevertheless, the mental health consequences remain unknown.

The period of childhood and adolescence is incredibly important to develop normal health behaviours which result in health consequences in adult life. Therefore, it seems vital to emphasise during the course of health education the significance of these behaviours for normal physical and psychosocial functioning and not just focusing on body mass indices.

Our research confirmed a significant correlation between health behaviours and body evaluation. We found that it is not body mass that affects body satisfaction, but proper health behaviours. This statement is essential especially considering nutritionists' reports on young people often taking up unhealthy eating practices in order to reduce body weight (e.g. 'wonder diets'). However, as the analysis of our research findings revealed, body mass does not significantly affect the positive feelings for body in the youth involved in the study. A significant correlation was also found between the overall intensity of health-conducive behaviours and the way that 17-18-year-old girls perceive and evaluate their body image. It was found that the more intense the health behaviours are, the more satisfied the girls are with their bodies and the more physically attractive they feel.

People during adolescence are incredibly susceptible to cultural patterns which influence health behaviours and determinants of beauty evaluation. Today's focus on human physicality implies the necessity of body care. Contemporary "western" culture establishes the determinants of human attractiveness including low body mass indicators. However, according to numerous studies, body care and aspiring to being attractive among youth often limit achieving and keeping a certain body weight and taking care of appearance (Andrew, Tiggemann, \& Clark, 2015). Still other studies reveal that taking care of appearance is not associated with health care. Consuming highly processed foods, fast food meals and applying starvation diets alternatively with diets excluding specific groups of food products may result in low weight, but they are not connected with maintaining good health. The general opinion among young people is that low body mass is an indicator of correct functioning of organism and that is why it is treated as an indicator of social adaptation. According to young people good looks - in the sense of resembling that of medial heroes - are equivalent to taking good care of oneself. Many young people believe that a good appearance is synonymous with health. Nevertheless, as numerous authors report, health behaviours of contemporary teenagers are alarmingly incorrect (Ravens-Sieberer, Kokonyei, \& Thomas, 2004). This may give rise to the conclusion that the term "health" is misunderstood by today's youth. Some teenagers are not aware of the fact that proper health behaviours determine normal psychosocial and physical functioning. We may suppose that some girls have limited knowledge about the conditions of health. These results indicate the necessity to modify the educational programmes at schools and (or) the "model of a beautiful body" created by some media addressed at adolescents (see http://www. newsweek.pl/styl-zycia/wyglad-cialo-piekno-akceptacja-kampanie-spoleczne,artykuly,364413,1.html).

Our research demonstrated that the body image of adolescent girls significantly correlates with their health care to a large extent and with the desire to be slim to a lesser extent. This is a very positive result considering the idea of a healthy lifestyle.

One of the more important variables related to evaluation of one's body is a positive mental attitude. Numerous studies have shown that a positive mental attitude is associated with better psychosocial functioning. The importance of this variable for body evaluation was confirmed in our studies. The schoolgirls who tried to avoid depressing situations, too strong emotions and stress were more contented with their bodies and gave a more positive body evaluation than their counterparts experiencing a lot of depressing situations and stress. Such an approach appears to be immensely important due to the large number of eating disorders in this period of life leading to anorexia, bulimia or the aforementioned skinny fat phenomenon or even to self-mutilation or other behavioural disorders (Hakkarainen et al., 2004). This result may provide a basis for initiating in-depth research on the significance of emotions experienced by adolescents for their physical activity and observing the rational diet principles and lifestyle.

A correlation was also found between health practices, which consisted of daily sleep habits, leisure as well as physical activity, and an overall body evaluation indicator. It was found that the higher was the
Health behaviour and body image 
Hanna Liberska, Klaudia Boniecka level of health behaviours presented by respondents, the more satisfied they were with their bodies. These findings appear to be particularly fascinating due to the alarmingly low level of normal health behaviours in many adolescents. Our studies revealed that proper health practices significantly correlate with better psychosocial functioning of teenagers.

Another relationship observed in the study concerns proper eating habits and body satisfaction. The schoolgirls involved in the research revealed higher evaluation of their bodies the more they cared about a proper diet and consumed whole-grain products, fruit and vegetables. A well-balanced diet does not only mean a good looking body and somatic health, but also better mental and social functioning (it is consistent with the definition of health adopted by the WHO). The correlations of eating habits with psychosocial functioning have biochemical connotations (Ravens-Sieberer et al., 2004; Hughes et al., 2003).

Based on the findings, we can specify the conditions for developing normal health behaviours among teenagers. From the above-mentioned studies there emerges an image of a young person who cares about his or her health and is contented with his or her body. This satisfaction is significantly associated with rational physical activity and rational diet. These comprise the components of health-oriented attitudes. Further research in this area would allow the development of the vital issue of body image during adolescence and would contribute to the development of proper health behaviours among youth. Owing to the large number of young people using restrictive diets, the present research may contribute to raising awareness of the importance of health behaviour for psychosocial functioning among adolescents. An excessively slim figure, as promoted by some mass media at present, does not provide a guarantee of satisfaction with one's body.

At this point an insufficient number of studies on health behaviours and body perception among boys should be mentioned. The observations revealed that many boys prefer the lifestyle leading to a skinny fat figure - without being aware of the health consequences.

\section{CONCLUSIONS}

The analysis of the correlation between health behaviours and body evaluation is a relatively new area of interest for researchers. The present study revealed a significant correlation between the level of health behaviours and body evaluation. Additionally, it was found that BMI does not correlate with own body satisfaction. An overall indicator of health behaviours and all the subscales, i.e. a positive mental attitude, preventive measures, proper eating habits and health practices, revealed a significant positive correlation with the level of body satisfaction and all the subscales, i.e. sexual attractiveness, weight control and physical condition, among the girls involved in the study.

The results indicate that a slim figure does not guarantee satisfaction with one's body in girls. The authors are aware of certain limitations of the research; for example, the study group included only girls, not boys. Currently similar research is being conducted in a younger age group and includes comparisons between boys and girls.

\section{RefERENCES}

Andrew, R., Tiggemann, M., \& Clark, L. (2015). Predictors of intuitive eating in adolescent girls. The Journal of Adolescent Health, 56, 209-214. doi: 10.1016/j.jadohealth.2014.09.005

Blair, S., Cheng, Y., \& Holder, J. (2001). Is physical activity or physical fitness more important in defining health benefits? Medicine \& Science in Sports \& Exercise, 33, 379-399.

Cash, T. F., Morrow, J. A., Hrabosky, J. I., \& Perry, A. A. (2004). How has body image changed? A cross-sectional investigation of college women and men from 1983 to 2001. Journal of Consulting and Clinical Psychology, 72, 1081-1089.

Cinelli, R. L, \& O’Dea, J. A. (2009). Body image and obesity among Australian adolescents from indigenous and Anglo-European backgrounds: implications for health promotion and obesity prevention among Aboriginal youth. Health Education Research, 24, 1059-1068. doi: 10.1093/her/cyp040

Davidson, M., \& Knafl, K. A. (2006). Dimensional analysis of the concept of obesity. Journal of $A d$ vanced Nursing, 54, 342-350.

Eisenberg, M. E., Neumark-Sztainer, D., \& Story, M. (2003). Associations of weight-based teasing and emotional well-being among adolescents. Archives of Pediatrics and Adolescent Medicine, 157, 733-738.

Epstein, L. H., Klein, K. R., \& Wisniewski, L. (1994). Child and parent factors that influence psychological problems in obese children. International Journal of Eating Disorders, 15, 151-158.

Franzoi, S. L., \& Shields, S. A. (1984). The Body-Esteem Scale: Multidimensional structure and sex differences in a college population. Journal of Personality Assessment, 48, 173-178.

Friedman, M. A., \& Brownell, K. D. (1995). Psychological correlates of obesity: Moving to the next research generation. Psychological Bulletin, 117, 3-20. doi: 10.1037/0033-2909.117.1.3

Hakkarainen, R., Partonen, T., Haukka, J., Virtamo, J., Albanes, D., \& Lonnqvist, J. (2004). Is low dietary intake of omega-3 fatty acids associated with depression? American Journal of Psychiatry, 161, 567-569. 
Hughes, J. H., Gallagher, P., Stewart, M. E., Matthews, D., Kelly, T. P., \& Young, A. H. (2003). The effects of acute tryptophan depletion on neuropsychological function. Journal of Psychopharmacology, 17, 300-309.

James, P. T., Rigby, N., \& Leach, R. (2004). The obesity epidemic, metabolic syndrome and future prevention strategies. European Journal of Preventive Cardiology February, 11, 13-18. doi: 10.1097/01. hjr.0000114707.27531.48

Juczyński, Z. (2001). Narzędzia pomiaru w promocji i psychologii zdrowia [NPPPZ. Assessment and diagnostic instruments for health psychology promotion]. Warszawa: Pracownia Testów Psychologicznych Polskiego Towarzystwa Psychologicznego.

Kelder, S. H., Perry, C. L., Klepp, K. I., \& Lytle, L. L. (1994). Longitudinal tracking of adolescent smoking, physical activity, and food choice behaviors. American Journal of Public Health, 84, 1121-1126. doi: 10.2105/AJPH.84.7.1121

Lalonde, M. (1974). A new perspective on the health of Canadians. Ottawa, Ontario, Canada: Minister of Supply and Services.

Lipowska, M., \& Lipowski, M. (2006). The evaluation of own attractiveness by females of different age. In A. Chybicka \& M. Kaźmierczak (eds.), The woman in the culture - the culture in the woman (pp. 385-402). Cracow: Oficyna Wydawnicza Impuls.

Lipowska, M., \& Lipowski, M. (2013). Polish normalization of the Body Esteem Scale. Health Psychology Report, 1, 72-81. doi: 10.5114/hpr.2013.40471

Must, A., \& Strauss, R. S. (1999). Risks and consequences of childhood and adolescent obesity. International Journal of Obesity and Related Metabolic Disorders, 23 Suppl 2, 2-11. doi: 10.1038/sj.ijo.0800852

O'Dea, J. A., \& Abraham, S. (2000). Improving the body image, eating attitudes, and behaviors of young male and female adolescents: a new educational approach that focuses on self-esteem. International Journal of Eating Disorders, 28, 43-57. doi: 10.1002/(SICI)1098-108X(200007)28:13.0.CO;2-D

Paeratakul, S., Ferdinand, D. P., Champagne, C. M., Ryan, D. H., \& Bray, G. A. (2003). Fast-food consumption among US adults and children: dietary and nutrient intake profile. Journal of the American Dietetic Association, 103, 1332-1338.

Ravens-Sieberer, U., Kökönyei, G., \& Thomas, C. (2004). School and health. In C. Currie, C. Roberts, A. Morgan, R. Smith, W. Settertobulte, O. Samdal, \& V. B. Rasmussen (eds.), Young people's health in context. Health Behaviour in School-aged Children (HBSC) study: international report from the 2001/2002 survey (pp. 184-195). Issue 4. Copenhagen: WHO Regional Office for Europe.

Schwartz, M. B., \& Brownell, K. D. (2004). Obesity and body image. Body Image, 1, 43-56. doi: 10.1016/S1740-1445(03)00007-X
Seidell, J. C. (1995). Obesity in Europe: scaling an epidemic. International Journal of Obesity and Related Metabolic Disorders, 19 Suppl 3, 1-4.

Słonka, K., \& Rektor, Z. (2005). Wybrane elementy stylu życia studentów kształcących się na specjalnościach związanych z medycyną [Chosen life style elements of medicine related faculties students]. Annales UMCS Medicina. Promocja zdrowia w hierarchii wartości [Health promotion in the hierarchy of values] (pp. 125-129). Lublin: NeuroCentrum.

Thompson, K. J., Coovert, M. D., Richards, K. J., Johnson, S., \& Cattarin, J. (1995). Development of body image, eating disturbance, and general psychological functioning in female adolescents: Covariance structure modeling and longitudinal investigations. International Journal of Eating Disorders, 18, 221-236.

Tiggemann, M. (2004). Body image across the adult life span: Stability and change. Body Image, 1, 29-41.

Vereecken, C. A., de Henauw, S., \& Maes, L. (2005). Adolescents' food habits: results of the Health Behaviour in School-aged Children Survey. British Journal of Nutrition, 94, 423-431.

Vila, G., Zipper, E., Dabbas, M., Bertrand, C., Robert, J. J., Ricour, C., \& Mouren-Siméoni, M. C. (2004). Mental disorders in obese children and adolescents. Psychosomatic Medicine, 66, 387-394.

http://www.newsweek.pl/styl-zycia/wyglad-cialopiekno-akceptacja-kampanie-spoleczne,artykuly, 364413,1.html
Health behaviour and body image 